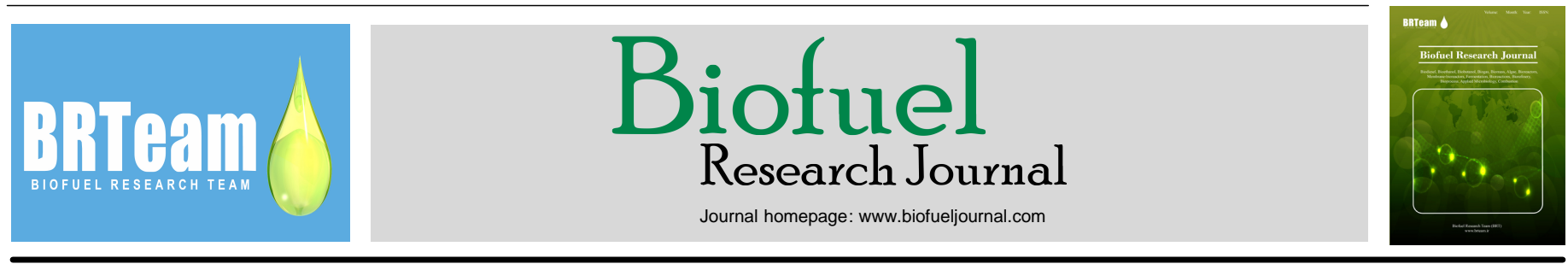

Review Paper

\title{
Recent updates on biogas production - a review
}

\section{Ilona Sárvári Horváth ${ }^{1, *}$, Meisam Tabatabaei ${ }^{2,3}$, Keikhosro Karimi ${ }^{4,5}$, Rajeev Kumar $^{6}$}

${ }^{1}$ Swedish Centre for Resource Recovery, University of Borås, 50190 Borås, Sweden.

${ }^{2}$ Microbial Biotechnology Department, Agricultural Biotechnology Research Institute of Iran (ABRII), AREEO, Karaj, Iran.

${ }^{3}$ Biofuel Research Team (BRTeam), Karaj, Iran.

${ }^{4}$ Department of Chemical Engineering, Isfahan University of Technology, Isfahan 84156-83111, Iran.

${ }^{5}$ Microbial Industrial Biotechnology Group, Institute of Biotechnology and Bioengineering, Isfahan University of Technology, Isfahan 84156-83111, Iran.

${ }^{6}$ Center for Environmental Research and Technology (CE-CERT), Bourns College of Engineering, University of California, Riverside, California, USA.

\section{HIGHLIGHTS}

$>$ Biogas; a promising renewable alternative for natural gas with similar applications.

$>$ Biogas can be produced from different types of

organic wastes.

$>\mathrm{AD}$ process is accompanied with several

environmental advantages compared with

incineration, landfilling, and composting.

$>$ Besides energy, $\mathrm{AD}$ process generated a nutrient-

rich biological fertilizer.

$>$ Recent developments in metagenomics techniques

have provided valuable tools to achieve improved

$\mathrm{AD}$ process.

\section{GRAPHICAL ABSTRACT}

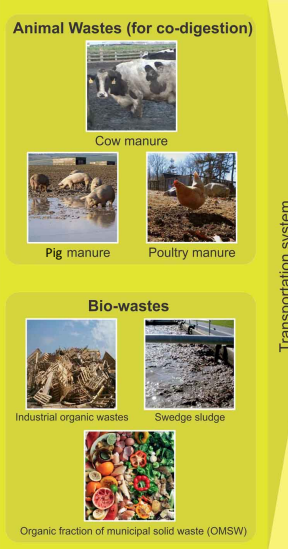

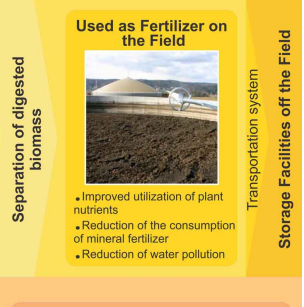

Biogas for Heat \& Power Generation

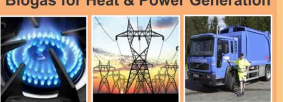

Renewable energy source . $\mathrm{CO}_{2}$-neutral Reduction of air pollution Effective energy utillization

\section{ARTICLE INFO}

\section{Article history:}

Received 12 March 2016

Received in revised form 13 May 2016

Accepted 16 May 2016

Available online 1 June 2016

\section{Keywords:}

Biogas plants

Anaerobic digestion (AD)

Anaerobic membrane reactor

Microbial community analysis

Metagenomics

\begin{abstract}
One of the greatest challenges facing the societies now and in the future is the reduction of green house gas emissions and thus preventing the climate change. It is therefore important to replace fossil fuels with renewable sources, such as biogas. Biogas can be produced from various organic waste streams or as a byproduct from industrial processes. Beside energy production, the degradation of organic waste through anaerobic digestion offers other advantages, such as the prevention of odor release and the decrease of pathogens. Moreover, the nutrient rich digested residues can be utilized as fertilizer for recycling the nutrients back to the fields. However, the amount of organic materials currently available for biogas production is limited and new substrates as well as new effective technologies are therefore needed to facilitate the growth of the biogas industry all over the world. Hence, major developments have been made during the last decades regarding the utilization of lignocellulosic biomass, the development of high rate systems, and the application of membrane technologies within the anaerobic digestion process in order to overcome the shortcomings encountered. The degradation of organic material requires a synchronized action of different groups of microorganisms with different metabolic capacities. Recent developments in molecular biology techniques have provided the research community with a valuable tool for improved understanding of this complex microbiological system, which in turn could help optimize and control the process in an effective way in the future.
\end{abstract}

(C) 2016 BRTeam. All rights reserved.

Corresponding author at: Tel.: +46-(0)33-435 4684

E-mail address: ilona.horvath@hb.se

Please cite this article as: Sárvári Horváth I., Tabatabaei M., Karimi K., Kumar R. Recent updates on biogas production - a review. Biofuel Research Journal 10 (2016) 394-402. DOI: 10.18331/BRJ2016.3.2.4 


\section{Contents}

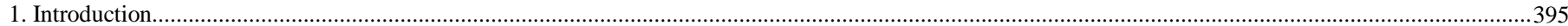

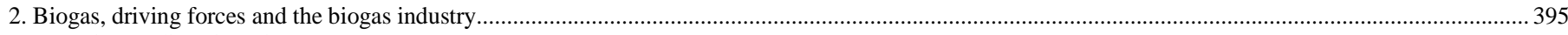

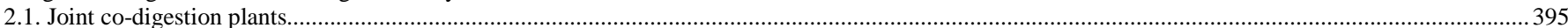

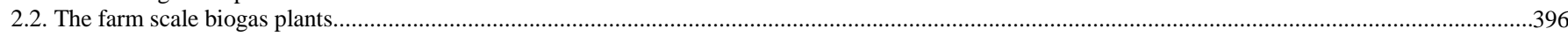

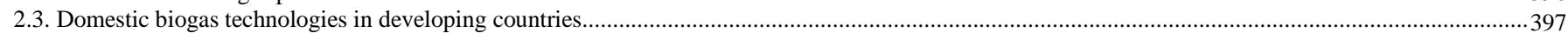

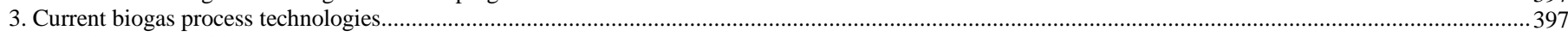

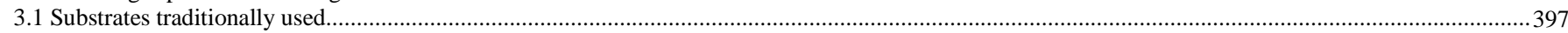

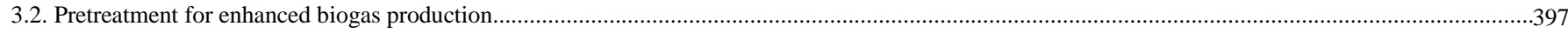

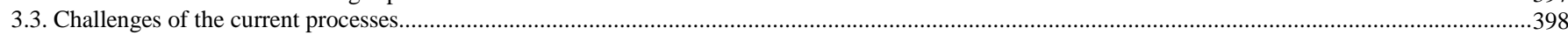

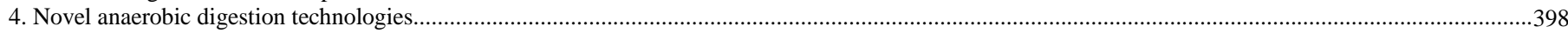

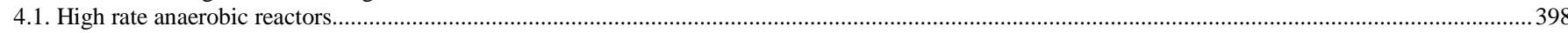

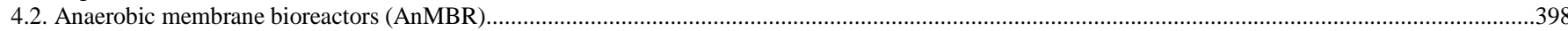

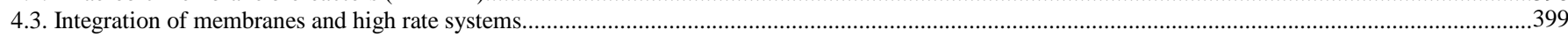

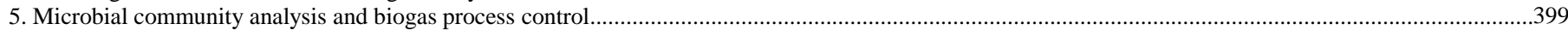

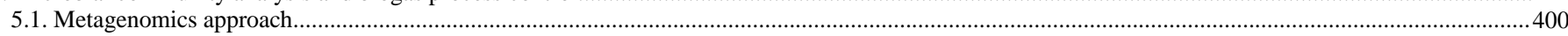

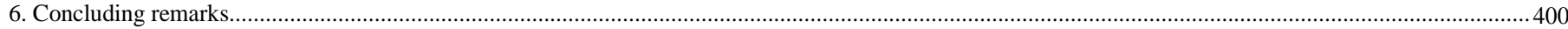

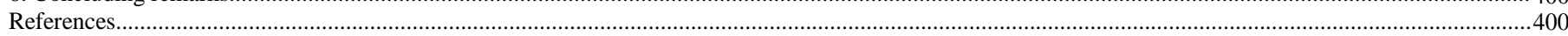

\section{Introduction}

Biogas production through anaerobic digestion (AD) is an environmental friendly process utilizing the increasing amounts of organic waste produced worldwide. A wide range of waste streams, including industrial and municipal waste waters, agricultural, municipal, and food industrial wastes, as well as plant residues, can be treated with this technology. It offers significant advantages over many other waste treatment processes. The main product of this treatment, i.e., the biogas, is a renewable energy resource, while the byproduct, i.e., the digester residue, can be utilized as fertilizer because of its high nutrient content available to plants (Ward et al., 2008). The performance of the AD process is highly dependent on the characteristics of feedstock as well as on the activity of the microorganisms involved in different degradation steps (Batstone et al., 2002). The conversion of organic matters into biogas can be divided in three stages: hydrolysis, acid formation, and methane production. In these different stages which are however carried out in parallel, different groups of bacteria collaborate by forming an anaerobic food chain where the products of one group will be the substrates of another group. The process proceeds efficiently if the degradation rates of the different stages are in balance (Yong et al., 2015).

This review presents an overview of the biogas industry worldwide and discusses some new technologies aiming at utilizing new substrates and enhancing the efficiency of the process.

\section{Biogas, driving forces and the biogas industry}

There is an increasing interest in bioenergy production across the world for environmental as well as economic and social reasons. The production of biogas contributes to the production of renewable and sustainable energy since biogas works as a flexible and predictable alternative for fossil fuels. The main political driving forces linked to the biogas system has a countryspecific variation (Huttunen et al., 2014). Within the European Union, well-developed biogas industry can be found in Germany, Denmark, Austria, and Sweden followed by the Netherlands, France, Spain, Italy, the United Kingdom, and Belgium. In these countries, with a strong agro-sector, reduction of nutrient emissions and renewable energy production are equally strong driving forces supporting biogas production. In other countries, like Portugal, Greece, and Ireland, as well as in many of the new East-European member states, the biogas sector is currently under development, due to the identified large potential for biomass utilization there.

The biogas plants in Europe are classified based on the type of digested substrates, the technology applied, or the size of the plant. In this sense, they are usually considered as (1) large scale, joint co-digestion plants or (2) farm scale plants. Nevertheless, there are no major differences between these two categories regarding the technology used.

\subsection{Joint co-digestion plants}

Simultaneous digestion of a mixture of two or more substrates is called co-digestion. The coexistence of different types of residues in the same geographic area enables integrated management, offering considerable environmental benefits, like energy savings, recycling of nutrients back to the agricultural land, and reduction of $\mathrm{CO}_{2}$ emissions (Kacprzak et al. 2010).

Due to the different characteristics of waste streams treated together, co-digestion may enhance the performance of the $\mathrm{AD}$ process owing to a positive synergism established in the digestion medium by providing a balanced nutrient supply and sometimes by suitably increasing the moisture content required in the digester (Mata-Alvarez et al., 2000).

Joint biogas plants are referred to large scale plants, with digester capacities ranging from few hundreds $\mathrm{m}^{3}$ up to several thousands $\mathrm{m}^{3}$. Different organic waste streams are collected and transported to the plant and co-digested there. The process is running either at thermophilic or mesophilic conditions, using hydraulic retention times (HRT) of 12-25 d HRT is normally inversely proportional to the process temperature. Generally, the substrates and in particular animal by-products, which are to be sent to the digester, first go through a controlled pre-sanitation phase, to inactivate pathogens and to break their propagation cycles. After the $\mathrm{AD}$ process, the digested residue is transferred to storage tanks, which are typically covered with a gas proof membrane for the recovery of the remaining gas and to prevent methane leakage to the atmosphere. The digested residue has a high nutrient content, and therefore, it can be recycled to the fields as fertilizer. The produced biogas is utilized as a renewable energy source.

In Europe, biogas is mainly used for generating heat and electricity. Some of the produced heat is utilized within the biogas plant as process heating and the remaining heat is distributed through districts heating systems to consumers. The produced power is sold to the grid. In some countries, like Sweden, the produced biogas is upgraded to bio-methane which is utilized as vehicle fuel (Nielsen et al., 2002; Persson et al., 2006). Figure 1 shows the biogas production cycle within an integrated system.

Recently, co-digestion has taken much attention since it is one of the interesting ways of improving the yield of $\mathrm{AD}$. Most of the investigations on co-digestion were carried out in batch operation mode and many researchers have pointed out the influence of synergy, due to a balanced mixture composition, on methane yield (Misi and Forster, 2001; Pagés Díaz et al., 2011; Esposito et al., 2012; Wang et al., 2012; Pagés-Díaz et al., 2014). Pagés-Díaz et al. (2011) reported that it was possible to relate synergetic effects with up to $43 \%$ enhancement in methane yield $\left(\mathrm{Y}_{\mathrm{CH} 4}\right)$ compared with the expected $\mathrm{Y}_{\mathrm{CH} 4}$ calculated on basis of methane potentials obtained for the individual substrates. The substrates investigated were 


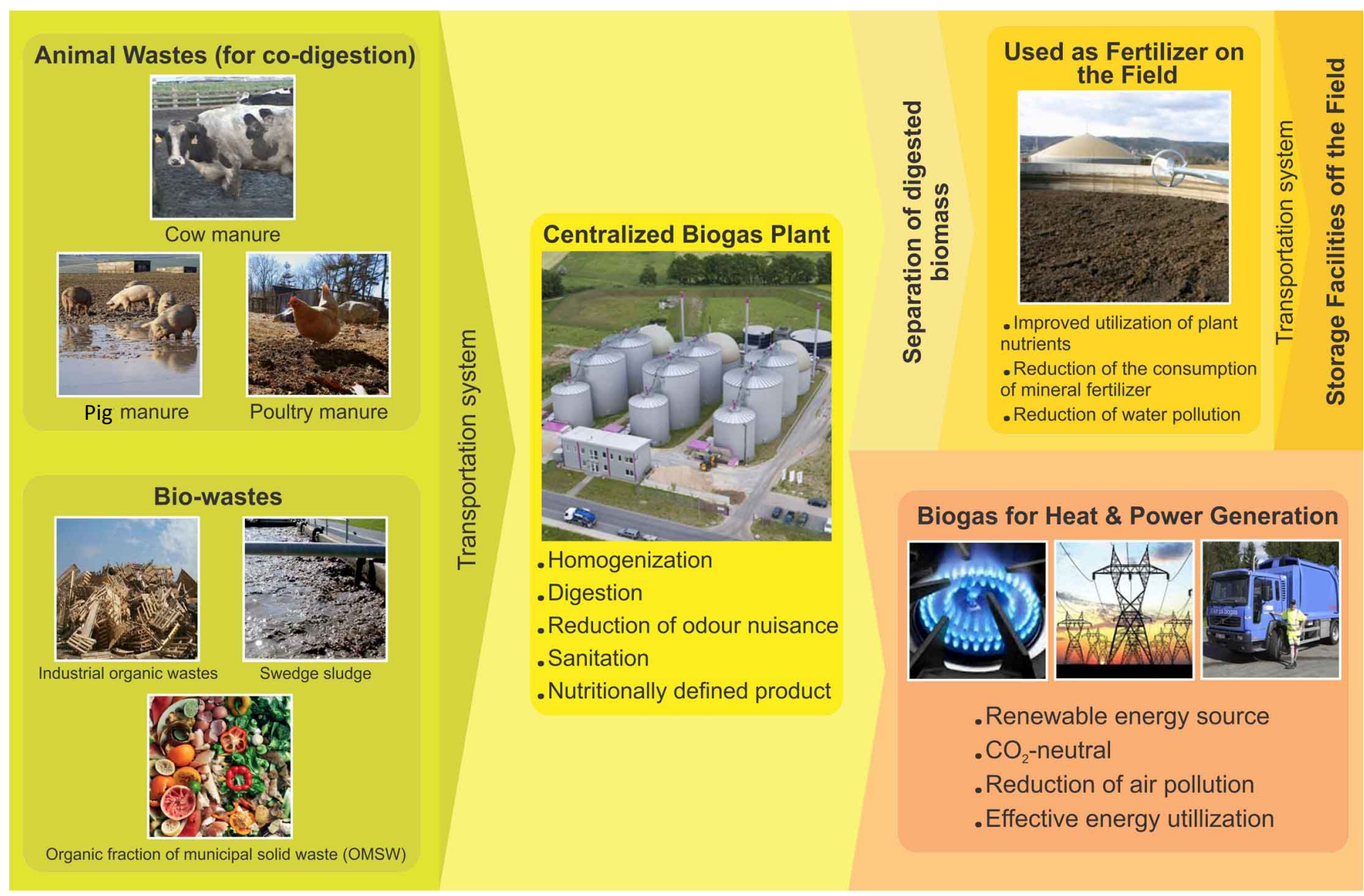

Fig.1. The main streams of the integrated concept of a centralized biogas plant (adapted from Holm-Nielsen et al., 2004).

four different waste streams, such as slaughterhouse waste, various crop residues, manure, and the organic fractions of municipal solid waste (OMSW). A successful co-digestion is not simply a digestion of several waste streams treated at the same time. In fact, biogas production and the stability of the process are highly dependent on waste composition, process conditions, and the activity of microbial community in the system. In that sense, for certain mixing ratios, co-digestion may also lead to antagonistic interactions, resulting in methane yields lower than expected (Pagés-Díaz et al., 2014 and 2015).

\subsection{The farm scale biogas plants}

It has been reported that more than 4,000 farm scale biogas digesters were in operation in Germany; followed by about 350 in Austria, 72 in Switzerland, 65 in the United Kingdom, 35 in Denmark, and 12 in Sweden (Raven and Gregersen, 2007; Wilkinson, 2011). The main substrate fractions, which are utilized in these farm scale biogas plants are animal manure and energy crops. One of the important aspects of biogas production for farmers is to reduce leaching of nutrients from agricultural lands to the aquatic environments (Bojesen et al., 2014). Hence, farm scale plants are usually established at large pig farms, aiming at solving the problems caused by the excessive slurry production. Figure 2 presents the closed cycle of organic waste $\mathrm{AD}$ and the main steps involved in the quality management process. The most common and recent digester type that is used in farm scale applications is a vertical tank generally made of concrete and equipped with a flexible membrane and light roof making it possible to be used as digester and gas-storage tank simultaneously. The average digester size here is typically from a couple of hundreds to one thousand $\mathrm{m}^{3}$ (Garcia, 2005).

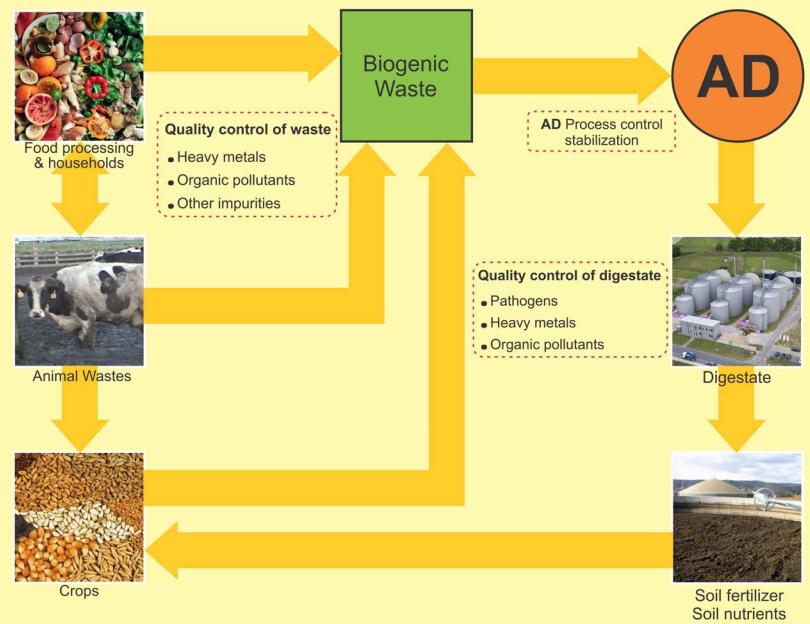

Fig.2. Schematic representation of the closed cycle of anaerobic digestion of organic waste and the main steps involved in the quality management process (adapted from Al Seadi (2002)). 


\subsection{Domestic biogas technologies in developing countries}

Domestic biogas digesters are abundant in developing countries, especially Asian countries, such as Nepal or Vietnam. Prior to the development of domestic biogas projects, it is important to check the current biogas diffusion in a given country in order to realize the maturity of the sector. The definition of national diffusion targets (i.e., a targeted amount of biogas units that should be built within a specified time frame) by the governments also provides information about the actual diffusion levels. In many countries already promoting domestic biogas production, the governments have implemented national programs aiming at establishing a proper biogas sector. Such programs typically include financing schemes, as well as training campaigns for local workforce, and providing technical support to project developers. These programs involve different players including non-profit organizations cooperating together with the local public institutions and the private sector in order to benefit potential synergies. The German GIZ (Society for International Cooperation, formerly GTZ) and the Dutch SNV are the two main international organizations acting worldwide for domestic biogas advancement, delivering technical service and documentation on this issue.

Some countries like India, Nepal, and China host much more domestic biogas plants than others. It has been reported that about 250,000 domestic plants were installed within the past 20 years in Nepal and 125,000 in Vietnam. Furthermore, 12,500 domestic biogas units are planned to be installed by the end of 2016 in Rwanda, 8,000 in Kenya, and 12,000 plants in Tanzania (Rakotojaona, 2013; TDBP, 2013; Cheng et al., 2014). The domestic biogas plant development is only at an earlier stage in Peru compared with the other Latin American countries. In 2013, the Dutch development organization in cooperation with the Peruvian, planned to set up a national program to construct 10,000 domestic biogas plants within the next 5 years (Rakotojaona, 2013).

\section{Current biogas process technologies}

The production of biogas through $\mathrm{AD}$ offers major advantages over other forms of bioenergy production. In fact, it has been defined as one of the most energy-efficient and environmentally beneficial technology for bioenergy production (Deublein and Steinhauser, 2011). The degradation process can be divided into four phases: hydrolysis, acidogenesis, acetogenesis, and methanogenesis; and in each individual phase, different groups of facultative or obligatory anaerobic microorganisms are involved as shown in Figure 3 (Merlin Christy et al., 2014; Chasnyk et al., 2015; Abdeshahian et al., 2016).

Beside energy production, the degradation of organic waste also offers some other advantages including the reduction of odour release and decreased level of pathogens. Moreover, the nutrient rich digested residue could be used as organic fertilizer for arable land instead of mineral fertilizer, as well as an organic substrate for green house cultivation (De Vries et al., 2012; Abdeshahian et al., 2016). Among the raw substances, organic materials obtained from farm and animal waste streams, as well as from industrial and household activities are pivotal sources for biogas production. as municipal solid waste (MSW), agricultural residues, and wastes from industrial activities. According to a 2012 world bank report, 1.3 billion tons of MSW was generated per year by 3 billion urban residents all over the word, which will increase to 2.2 billion tons by 2025 (Hoornweg and Bhada-Tata, 2012). MSW mainly consists of food waste, paper and paperboard, yard trimmings, wood, plastic, metal, and glass. However, its composition differs depending on regions and countries in which it is collected. To be able to utilize this fraction for biogas production, all the inert material, including plastic, metal, and glass should be removed prior to $\mathrm{AD}$. Moreover, around 15 billion tons of waste, like crops residues and animal manure, is generated worldwide annually from the agricultural sector (Donkin et al., 2013).

Food processing industries also generate waste, however the estimation of its amount is excessively difficult, since it greatly depends on the industry and technology applied. As an example, in the juice producing industry up to $50 \%$ of the processed fruit will end up as waste. Moreover, $30 \%$ of the weight of a chicken is not suitable for human consumption, and it is therefore removed as waste during slaughtering and other processing steps (Salminen and Rintala, 2002; Forgács et al., 2012).

Although all these different waste fractions are suitable for biogas production, their biogas potential varies significantly. The biogas yield mainly depends on the composition and the biodegradability (under anaerobic conditions) of the waste. Theoretically, the highest biogas yield can be achieved from lipids $\left(1.01 \mathrm{Nm}^{3} \mathrm{CH}_{4} / \mathrm{kg} \mathrm{VS}\right)$, followed by proteins $\left(0.50 \mathrm{Nm}^{3} \mathrm{CH}_{4} / \mathrm{kg} \mathrm{VS}\right)$, and carbohydrates $\left(0.42 \mathrm{Nm}^{3} \mathrm{CH}_{4} / \mathrm{kg} \mathrm{VS}\right)$ (Møller et al., 2004). On the other hand, biodegradability defines how much of a given material is actually utilized during the process. Some compounds like sugars degrade fast and completely, while the degradation of some other materials take longer times, as for example, lignocelluloserich biomass degrades at very low rates.

\subsection{Pretreatment for enhanced biogas production}

The growing global energy demand together with the limited availability of fossil fuels, unstable energy prices, and environmental problems necessitate the use of renewable energies. The currently used feedstocks for $\mathrm{AD}$ are limited, and therefore, it is important to explore new substrates for their utilization in $\mathrm{AD}$ to reserve the growing needs. The abundance and availability of lignocellulosic biomasses worldwide as well as their high carbohydrate content make these materials an attractive feedstock for biofuel production. Lignocelluloses have been accounted for approximately $50 \%$ of the biomass in the world and the production of lignocelluloses can count up to about 200 billion tons per year (Claassen et al., 1999; Zhang, 2008). Currently, the utilization of lignocellulosic residues as feedstock for methane production is not widespread (Lehtomäki, 2006; Seppälä et al., 2007) due to their recalcitrant structure, which is the main challenge (Hendriks and Zeeman, 2009).

During the first step of $\mathrm{AD}$, i.e., in the hydrolysis step, the hydrolytic bacteria convert the insoluble complex organic matters into monomers

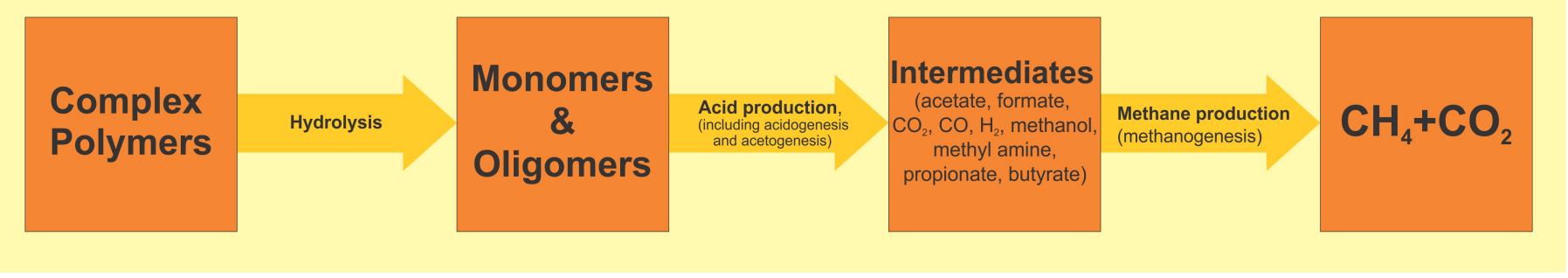

Fig.3. The degradation process taking place during $\mathrm{AD}$, i.e., hydrolysis, acidogenesis, acetogenesis, and methanogenesis.

\subsection{Substrates traditionally used}

Through human activities, a huge amount of organic solid waste is generated, which as discussed earlier can be used as feedstock for biogas production. Based on the origin, the different waste streams can be classified and soluble oligomers such as fatty acids, amino acids, and sugars (Fig. 3). The enzymes involved in this process are cellulases, hemicellulases, lipases, amylases, and proteases (Taherzadeh and Karimi, 2008). Therefore, in biogas processes, almost all kinds of substrates can be hydrolyzed. However, the rate of the hydrolysis step is highly dependent 
on the characteristics of a given substrate. Hydrolysis can proceed relatively fast if the necessary enzymes are produced by microorganisms and suitable surface area for physical contact between the enzymes and the substrate is provided (Taherzadeh and Karimi, 2008). Nevertheless, substrates with more recalcitrant structure, like cellulose, need longer period to be degraded, and the degradation is usually not complete (Deublein and Steinhauser, 2011). Hence, the hydrolysis step is often considered as the rate-limiting step when utilizing these kinds of substrates (Vavilin et al., 1996; Taherzadeh and Karimi, 2008).

Therefore, an initial pretreatment step, which converts raw materials to a form that is amenable to microbial and enzymatic degradation is needed (Zhang, 2008). A suitable pretreatment by the disruption of the secondary cell walls structure will reduce biomass recalcitrance and thus facilitate downstream processes. Optimally, a pretreatment should also be costeffective and yield a polysaccharidic-rich substrate with limited amounts of inhibitory by-products.

A numbers of pretreatment methods have been suggested for enhancing biogas production from lignocellulosic biomass, which can be classified as, physical, physicochemical, chemical, and biological pretreatments (Chandra et al., 2007; Taherzadeh and Karimi, 2008; Yang and Wyman, 2008; Hendriks and Zeeman, 2009). Milling, among the physical pretreatments was proven to be effective by shearing, increasing the specific surface area, and reducing the degree of polymerization (DP), thus improving the hydrolysis yield by $5-25 \%$. Degree of such improvement depends on type of biomass, as well as the duration and type of milling (Jin and Chen, 2006; Zeng et al., 2007). Overall, it has been repeatedly shown that smaller particle sizes result in higher yields (Jin and Chen, 2006; Monavari et al., 2009; Lennartsson et al., 2011; Teghammar et al., 2012). That is why the physical pretreatment is often carried out in combination with other pretreatment methods. However, in some cases, the chemical agent used for the pretreatment can act as a potential inhibitor for the microbial community involved in the $\mathrm{AD}$. In a recent study, it was found that the remaining solvent affected the digestion process negatively when forest residues was pretreated with an organic solvent, N-methylmorpholine-N-oxide, even at concentrations as low as $0.008 \%$ (Kabir et al., 2013). Besides, the pretreatment process itself might lead to the production of inhibitory products; and despite optimization of pretreatment conditions, some inhibitors will still occur in the pretreated slurry. These may be either degradation products, such as furans through dilute-acid hydrolysis and steam explosion pretreatments, and furfural through alkaline pretreatments, or biomass constituents of varying molecular weights and concentrations (Ahring et al., 1996; Taherzadeh and Karimi, 2008).

Recently, it was shown that using alcohols or weak organic acid for the pretreatment of lignocelluloses seems to be an interesting method. Since they are intermediary products during the anaerobic degradation process, the above-mentioned inhibitory problems can be avoided and moreover, the remaining traces of these solvents after the pretreatment can be consumed for additional methane production. In a recent study, Kabir et al. (2015) applied ethanol, methanol, or acetic acid for the pretreatment of forest residues prior to $\mathrm{AD}$. It was found that although according to the batch experimental results, treatments with ethanol or acetic acid resulted in higher methane yields; the techno-economic calculations showed that treatment with methanol was economically more feasible due to the lower price of methanol and the lower costs for its recovery after the treatment.

\subsection{Challenges of the current processes}

In general and as mentioned earlier, the $\mathrm{AD}$ of organic material requires combined activity of several different groups of microorganisms with different metabolic capacities (Himmel et al., 1994). To obtain a stable biogas process, all the conversion steps involved in the degradation of organic matters and the microorganisms carrying out these steps must work in a synchronised manner. Methanogens have longer duplication times (of up to $30 \mathrm{~d}$ ) and are generally considered as the most sensitive group to process disturbances (Griffin et al., 1998). It is therefore important to prevent these groups of microorganisms from being washed out from the system, by decoupling the solid retention time (SRT) and the HRT. Major developments have been therefore made during the last decades with regard to development of high rate systems, lowering the effects of toxic compounds, integrating the biological process with membrane separation techniques, as well as better understanding of anaerobic metabolism, and interactions among different microbial species.

\section{Novel anaerobic digestion technologies}

AD systems have undergone several modifications in the last decades to increase the efficiency of the process. In this sense and aiming at overcoming the methanogenesis as the rate-limiting step, efficient retention of the slow-growing methanogenic biomass has been the most important challenge. An important milestone was the development of a new reactor design, i.e., the up flow anaerobic sludge blanket (UASB) reactor, containing a well-settleable methanogenic sludge due to the formation of a dense sludge bed. Another technology making possible to retain active biomass within the system was the application of membrane bioreactors (MBRs). Besides separating cells, the membrane can also be used for the separation of inhibitory compounds, which otherwise would negatively affect the biological process, or for in situ recovery of the product could result in decreased cost of down stream processing. Additionally, the development of molecular biology techniques provided researchers with a valuable tool to understand the complex microbiological system involved in anaerobic degradation of organic matters. By the application of these techniques, it would be possible to regulate and control the process and discover disturbances much earlier then using traditional process parameters for monitoring the process.

\subsection{High rate anaerobic reactors}

The UASB reactor, which was developed by Dr. Gatze Lettinga in the Netherlands during the early 70 s, is probably the most popular high-rate reactor system applied for anaerobic biological treatment of "wastewater", as more than 1000 UASB reactors are in operation throughout the World This process is attractive because of its compactness, high loading rates, relatively low retention times for anaerobic treatment, low operational cost, low sludge production, and high methane production rates. The granular or flocculated sludge is the main prominent characteristic of this type of reactors as compared with other anaerobic technologies. In an UASB reactor, anaerobic microorganisms can form granules through selfimmobilization of the cells, and the performance of the system is strongly dependent upon the granulation process together with the characteristics of a particular wastewater treated (Schmidt and Ahring, 1996). Thus, changing the waste type will also affect the sludge quality and thereby the efficiency of the process. Moreover, substrates with a high fraction of particulate organic material are not suitable to be treated with this technology. A modified reactor configuration was therefore proposed recently aiming at separating the hydrolysis and acid formation steps from the methanogenesis step when treating MSW using a two-stage process including a continuously stirred tank reactor (CSTR) and an UASB reactor (Aslanzadeh, 2014). Comparing the performance of this two-stage system with that of a traditional one stage digestion, it was found that using this novel technology, organic loading rate (OLR) of $10 \mathrm{gVS} / \mathrm{L} / \mathrm{d}$ could be achieved while the HRT could be reduced to $3 \mathrm{~d}$.

\subsection{Anaerobic membrane bioreactors (AnMBR)}

In membrane bioreactors (MBRs), the membrane forms a selective barrier allowing certain components to pass while retaining others, thereby the biological system can be protected. The application of MBRs provides both increased SRT by avoiding the wash out of the cells and decreasing inhibitor concentrations by the separation of inhibitors (Visvanathan and Abeynayaka, 2012).

Today, there are two different designs for membrane bioreactors applied. The membrane can be placed either in an external loop or submerged within the reactor (Fig. 4).

The submerged system requires less space and energy, since compared with the external loop system, energy input is not required to maintain a continuous flow through the membrane. However, it could be problematic to operate this system at high particulate and/or cell concentrations, due to fouling (Judd, 2010). Membrane technologies developed and applied in waste water treatment processes can also be used for biogas production processes. Different studies on membrane technologies in biogas systems 
a
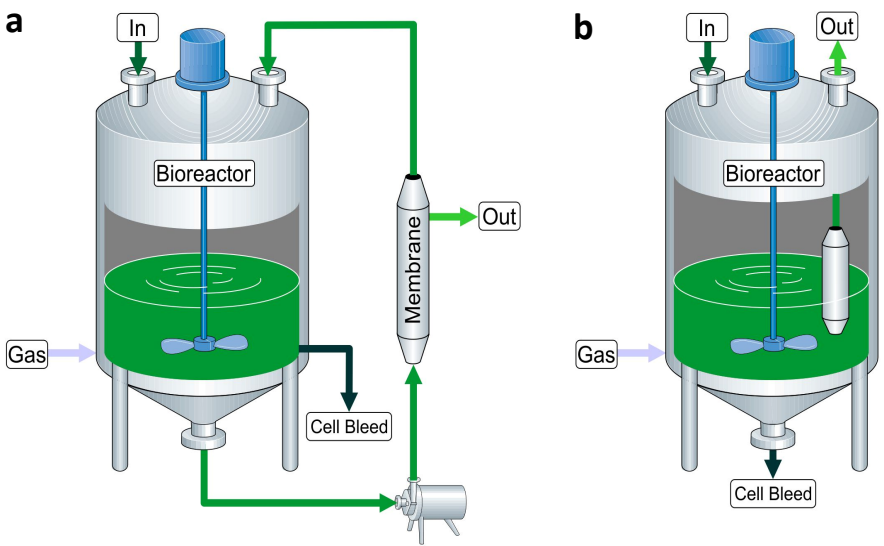

Fig.4. Membrane bioreactor designs; a) external loop, b) submerged (adapted from Ylitervo et al. (2013)).

reported yields comparable with those obtained with high rate systems, i.e., UASB systems (Lin et al., 2011; Wijekoon et al., 2011).

Encapsulation of methane-producing bacteria was carried out to test the viability of this technique in biogas processes. One-step liquid-dropletforming method was used to form spherical capsules of alginate. Chitosan or $\mathrm{Ca}^{2+}$ was used as counter-ions together with the addition of carboxymethyl cellulose. Furthermore, a synthetic Durapore ${ }^{\circledR}$ membrane (hydrophilic polyvinyldifluorid (PVDF)) was also tested by making encapsulating sachets with dimension of $3 \times 3$ or $3 \times 6 \mathrm{~cm}^{2}$ for holding the bacteria. The results indicated that these membranes allowed the penetration of nutrients into the cells while the gas produced could escape out of the capsules by diffusion. Hence, encapsulation can be a promising method, keeping high density of microorganisms in the system (Youngsukkasem et al., 2012). This theory was further investigated by comparing the ability of encapsulated cells with free cells to handle limonene containing synthetic media during AD. Limonene naturally occurs in citrus waste, making the utilization of this waste stream in biogas processes difficult, due to its inhibitory effects on the biogas producing microorganisms. The results showed the protective effect of the PVDF membrane resulting in faster biogas production by the encased bacteria compared to the free cells (Youngsukkasem et al., 2013).

Furthermore, a novel AnMBR configuration was investigated later, where both free cells and encased cells worked simultaneously in a single reactor treating a model substrate, Avicel, with limonene addition (Wikandari et al., 2014). The experiments were carried out at thermophilic conditions under semi-continuous operation at OLR of $1 \mathrm{gVS} / \mathrm{L} / \mathrm{d}$ and HRT of $30 \mathrm{~d}$. Generally, citrus waste contains $8 \mathrm{~g} / \mathrm{L}$ limonene, and it was found that this reactor configuration could overcome the inhibitor problem with the addition of up to $5 \mathrm{~g} / \mathrm{L}$ limonene. Thus, this technique has a potential to be applied for anaerobic digestion of fruit wastes containing certain inhibitory compounds.

As it was mentioned earlier, the recalcitrant structure makes the utilization of lignocellulosic biomass in biogas processes difficult. Besides the introduction of different pretreatment technologies prior to $\mathrm{AD}$ with an aim to open up their structure, another approach was recently introduced by processing the lignocellulosic biomass thermochemically instead, aiming at obtaining intermediary gases, called syngas. Syngas primarily contains carbon monoxide $(\mathrm{CO})$ hydrogen $\left(\mathrm{H}_{2}\right)$, and carbon dioxide $\left(\mathrm{CO}_{2}\right)$. Hence, this gas mixture can be utilized by the anaerobic microorganisms, using the $\mathrm{CO}$ and/or $\mathrm{CO}_{2}$ as carbon source and $\mathrm{H}_{2}$ as energy source, to produce methane. In order to increase the productivity and the efficiency of the conversion, a reverse MBR (RMBR) was applied retaining the cells inside the reactor (Youngsukkasem et al., 2015). Using anaerobic sludge encased in PVDF membranes, the conversion of syngas to methane could be carried out at a retention time of $1 \mathrm{~d}$. Furthermore, co-digestion of syngas with a synthetic organic medium was also successful by allowing the diffusion of both gas and liquid through the surface of the membrane.

\subsection{Integration of membranes and high rate systems}

The combination of anaerobic membrane technology and high rate systems is increasingly being investigated. These integrated systems have several advantages such as improved methane production and less fouling problems and are especially suitable to treat high strength industrial and municipal wastewaters aiming at achieving solids free effluents with a high degree of pathogen removal.

Kraft evaporator condensate was treated at mesophilic conditions with a submerged combined UASB-MBR system achieving a methane yield of $0.35 \mathrm{~L} \mathrm{CH}_{4} / \mathrm{gCOD}_{\text {removed }}$ which was very close to the theoretical yield of $0.397 \mathrm{~L} \mathrm{CH}_{4} / \mathrm{gCOD}$ at $37^{\circ} \mathrm{C}$ (Xie et al., 2010). However, seeding the UASB reactor with non-granule sludge required a long start up period (up to 3-4 months) to be able to achieve the formation of granules and hence, a stable biogas production. In that sense, the presence of a membrane in the reactor could eliminate the hydraulic pressure and negatively affect the granular sludge properties (Ozgun et al., 2013). Further investigations are therefore needed to determine the most optimal process configurations, i.e., the reactor type and the way of coupling it with the membrane module.

\section{Microbial community analysis and biogas process control}

As mentioned earlier, AD involves different degradation steps, i.e., hydrolysis, acidogenesis, acetogenesis, and methanogenesis that are facilitated by various groups of microorganisms (Fig. 3). These microorganisms can be divided into three functional groups: hydrolysing and fermenting bacteria, obligate hydrogen-producing acetogenic bacteria, and methanogenic archaea (Ahring, 2003). Hydrolytic acidogenic bacteria (HABs) hydrolyze complex organic polymers into simple compounds during the first step of the degradation. During the acidogenesis process, volatile fatty acids (VFA), alcohols, $\mathrm{H}_{2}$, and $\mathrm{CO}_{2}$ are produced. Similarly, acetic acid, $\mathrm{H}_{2}$, and $\mathrm{CO}_{2}$ are produced in the acetogenesis step by the obligate $\mathrm{H}_{2}$-producing acetogens. Syntrophobacter (PUAs: propionateutilizing acetogens) and Syntrophomonas (BUAs: butyrate-utilizing acetogens) represent the major part of acetogens. A key factor in the degradation is that anaerobic oxidation of butyrate and propionate occurs only in syntrophic association with $\mathrm{H}_{2}$-utilizing methanogens (HUMs), consuming $\mathrm{H}_{2}$ and $\mathrm{CO}_{2}$ for methane $\left(\mathrm{CH}_{4}\right)$ production, preventing the accumulation of increasing $\mathrm{H}_{2}$ pressure in the digester. Another way of methane formation is the conversion of acetate to $\mathrm{CH}_{4}$ and $\mathrm{CO}_{2}$ by the action of acetate-utilizing methanogens (AUMs) (Climent et al., 2007; Zahedi et al., 2013; Ennouri et al., 2016). In general, the operational parameters as well as substrate characteristics will influence the composition of the anaerobic microbial consortium present in a digester.

Molecular biology techniques provide valuable tools for improved understanding of microbial communities and their function in connection with different aspects of $\mathrm{AD}$, which in turn may help optimize the biogas production process more efficiently. A broad range of studies was published recently on investigations on microbial community structures in biogas reactors. The methodologies applied included analysis of total bacteria and archaeal community by targeting 16S rRNA using 454 next generation sequencing (NGS) technique (Zakrzewski et al., 2012) or terminal restriction fragment length polymorphism (T-RFLP) (Wang et al., 2010); as well as detection and quantification of methanogenic Archaea by quantitative real time polymerase chain reaction (qPCR) qPCR is a commonly used method in microbial community studies to detect and quantify a targeted DNA sequence. The principle of qPCR is very similar to that of conventional PCR. The target gene is amplified over a number of cycles. However, the conventional PCR allows only end point detection, whereas using a fluorescent dye or probe, the concentration of the target gene can be monitored after each cycle in qPCR. The detected change in fluorescence intensity reflects the concentration of the amplified gene in real time (VanGuilder et al., 2008).

Among the first studies aiming at understanding the relationship between biodiversity, operating conditions, and process performance, the prokaryotic community of seven digesters treating sewage sludge was examined by constructing and analyzing a total of 9890 16S rRNA gene clones. The results showed that the bacterial community could be divided in three components: one-third of the phylotypes could be found in most 
of the digesters, one-third were phylotypes shared among a few digesters, and the rest were specific phylotypes found under certain conditions (Riviere et al., 2009).

\subsection{Metagenomics approaches}

The traditional molecular biology technologies help with identifying only the most abundant microbial populations present in the reactor. Due to their high sequencing depth, the newly developed sequencing techniques make the determination of both the most abundant and also the minor populations possible. The NGS-based metagenomic approach enables following up changes in the microbial community structure starting from the very initial stage to souring of the digester. Coding gene sequences (mRNA) especially those representing critical steps of specific metabolic pathways can be mapped to assess the functional profiles of microbial communities. The high throughput sequencing-based metagenomic characterization of various microbial communities involved in biomethanation of a range of substrates has been elucidated with the help of 454 pyrosequencing and SOLiD NGS methods (Kovács et al., 2013; Sundberg et al., 2013; Pore et al., 2016). For example, the Ion Torrent PGM technique, which was launched in 2011, provided the highest throughput compared with that of 454 NGS and it was recently used for microbial composition analysis in several studies (Luo et al., 2013; Wang et al., 2013). Investigations on the microbial community in 21 full scale anaerobic digestion plants using 454 pyrosequencing of $16 \mathrm{~S}$ rRNA gene sequences showed that the bacterial community was always more abundant and more diverse than the archaeal community in all reactors. Moreover, it was found that while acetoclastic methanogens or AUMs were detected in plants digesting sewage sludge, they were absent in co-digestions plants. Hence, methane is generated from acetate mainly via syntrophic acetate oxidation in the co-digestion plants (Sundberg et al., 2013). To date, most studies have strived to investigate the microbial community inside the reactors without taking into account the whole biogas process chain.

Using Ion Torrent PGM technique, investigations on bacterial composition analysis and the presence of bacterial pathogens were performed recently by Luo and Angelidaki (2014) within the whole biogas producing system including the influent, the biogas reactor, and the post-digesters. They found that bacterial community composition of the influent was changed after AD. More specifically, the richness and relative abundance of bacterial pathogens reduced during $\mathrm{AD}$, however, an increase in the relative abundance of pathogens was observed after prolonged post digestion times of $30 \mathrm{~d}$. The authors pointed out that special attention should be therefore paid to the post digestion step aiming at avoiding the re-growth of bacterial pathogens, which otherwise will limit the disposal of the digested residue as bio-fertilizer. Similarly, the denaturing gradient gel electrophoresis (DGGE) technique is still among the promising methods to perform a preliminary analysis of the microbial community profile and to monitor the various experimental stages during the biogas production process. In a recent study, Dias et al. (2016) compared the sequences from DGGE bands with NCBI and RDP databases and reported the significant presence of Proteobacteria (6 from 7 sequences), specifically Gammaproteobacteria in the biogas system from vinasse methanisation.

In another study, the microbial community structure in a solid-state anaerobic digester (SS-AD) treating lignocellulosic residues, i.e., waste from palm oil mill industry or wheat straw was investigated. The samples were analyzed by $16 \mathrm{~S}$ rRNA gene (rrs) sequence analysis combined with PCRDGGE. The bacterial community in SS-AD was comprised of Ruminococcus sp., Thiomargarita sp., Clostridium sp., Anaerobacter sp., Bacillus sp., Sporobacterium sp., Saccharofermentans sp., Oscillibacter sp., Sporobacter sp., Lachnospiraceae sp., etc. (Heeg et al., 2014; Suksong et al., 2016).

Moreover, the high-throughput Illumina Miseq approach is also widely considered as a promising culture-independent method to perform microbial community analysis of AD systems. By the application of this method, the specific syntrophic relationships between acetogens and methanogens could be better understood, especially in terms of how it can be related to disturbances occurring in the biogas production process. Anaerobic digesters treating lipid-extracted microalgae residue at various inoculum-to-substrate ratios were investigated using Illumina Miseq analysis. Differences in the phylum distribution of the bacterial community were detected in accordance with the changes in inoculum to substrate ratios. The different levels of long chain fatty acids (LCFAs) affected each functional microbial group. Although methanogens were the most sensitive group to LCFA inhibition, the LCFA inhibition factor for hydrolytic bacteria was more highly affected by the inoculum to substrate ratios. Syntrophic acetogens showed a decreased abundance in case of high LCFA concentrations (Ma et al., 2015; Aydin, 2016)

\section{Concluding remarks}

The increasing demand for renewable energy compels the exploration of new substrates and the development of new technologies for biogas production. Regarding raw materials for $\mathrm{AD}$, it is preferable to utilize waste streams since in this way, the process addresses both waste reduction and energy production. Lignocellulosic residues are readily available; however, further development of novel pretreatment technologies are needed to achieve economically viable processes. Anaerobic degradation of organic material requires a well functioning microbial consortium, and methanogenic microorganisms, responsible for methane production within the final step of the digestion process, are known to be the most sensitive ones to process disturbances. This together with their slow growing rate made it necessary to develop novel process configurations aiming at preventing their wash out from the system. In this sense, the development of UASB reactor was an important milestone. In UASB system the formation of a dense well-settleable granular sludge makes an efficient decoupling of SRT and HRT possible. In better words, a crucial factor for a successful anaerobic high-rate treatment is the retention of all slow-growing microorganisms. Hence, when sludge granulation is hindered or lacking, membranes can be applied for biomass separation and recycling back into the reactor.

Therefore, the interest in using different membrane configurations is driven by the requirement for increasing productivity. However, with high particulate and/or cell concentrations, the operation of these kinds of systems can be problematic due to fouling. Thus, full-scale implementation of the AnMBR technology will be highly dependent on flux levels achieved during long-term operation. Finally, since AD is a complex microbial process, a broad range of studies have recently aimed at understanding the relationship between the microbial community structure, operating conditions, and process performance. By using nove newly-developed molecular biology tools, it would be possible to control and regulate the process in an effective way. To date, these techniques were mainly applied for the digestion step itself, however, it is necessary to pay attention to the whole biogas production system, including storage and feeding together with the post digestion step in the future as well.

\section{References}

[1] Abdeshahian, P., Lim, J.S., Ho, W.S., Hashim, H., Lee, C.T., 2016. Potential of biogas production from farm animal waste in Malaysia. Renew. Sust. Energy Rev. 60, 714-723.

[2] Ahring, B.K., Jensen, K., Nielsen, P., Bjerre, A.B., Schmidt, A.S. 1996. Pretreatment of wheat straw and conversion of xylose and xylan to ethanol by thermophilic anaerobic bacteria. Bioresour. Technol. 58(2), 107-113

[3] Ahring, B.K., 2003. Perspectives for anaerobic digestion, in: In Biomethanation I. Advances in biochemical engineering/biotechnology. 81, 1-30.

[4] Al Seadi, T., 2002. Quality management of AD residues from biogas production. Proc. IEA Bioenergy, Task 24 - Energy from Biological Conversion of Organic Waste.

[5] Aslanzadeh, S., 2014. Pretreatement of cellulosic waste and high rate biogas production. University of Borås, Borås, Sweden.

[6] Aydin, S., 2016. Enhancement of microbial diversity and methane yield by bacterial bioaugmentation through the anaerobic digestion of Haematococcus pluvialis. Appl. Microbiol. Biotechnol.100, 5631-5637.

[7] Batstone, D.J., Keller, J., Angelidaki, I., Kalyuzhnyi, S.V., Pavlostathis, S.G., Rozzi, A., Sanders, W.T.M., Siegrist, H., Vavilin, V.A., 2002. The IWA Anaerobic Digestion Model No 1 (ADM 1) Water Sci. Technol. 45(10), 65-73.

[8] TDBP, 2013. Tanzania Domestic Biogas Programme.

[9] Chandra, R.P., Bura, R., Mabee, W.E., Berlin, A., Pan, X., Saddler, J.N., 2007. Substrate pretreatment: The key to effective enzymatic 
hydrolysis of lignocellulosics?, In: Olsson L.(Ed.), Biofuels. Springer Berlin Heidelberg, pp. 67-93

[10] Chasnyk, O., Sołowski, G., Shkarupa, O., 2015. Historical, technical and economic aspects of biogas development: Case of Poland and Ukraine. Renew. Sust. Energy Rev. 52, 227-239.

[11] Cheng, S., Li, Z., Mang, H.P., Huba, E.M., Gao, R., Wang, X., 2014. Development and application of prefabricated biogas digesters in developing countries. Renew. Sust. Energy Rev. 34, 387-400.

[12] Claassen, P.A.M., Van Lier, J.B., Contreras, A.M.L., Van Niel, E.W.J., Sijtsma, L et al., 1999. Utilisation of biomass for the supply of energy carriers. Appl. Microbiol. Biotechnol. 52(6), 741-755.

[13] Climent, M., Ferrer, I., Baeza, M.d.M., Artola, A., Vázquez, F., Font, X., 2007. Effects of thermal and mechanical pretreatments of secondary sludge on biogas production under thermophilic conditions. Chem. Eng. J. 133(1), 335-342.

[14] Deublein, D., Steinhauser, A., 2011. Biogas from waste and renewable resources: an introduction. Mörlenbach, Germany: Wiley-VCH Verlag $\mathrm{GmbH} \& \mathrm{Co} . \mathrm{KGaA}$.

[15] de Vries, J.W., Vinken, T.M.W.J., Hamelin, L., De Boer, I.J.M., 2012. Comparing environmental consequences of anaerobic mono- and codigestion of pig manure to produce bio-energy - A life cycle perspective. Bioresour. Technol. 125, 239-248.

[16] Dias, M.F., Colturato, L.F., de Oliveira, J.P., Leite, L.R., Oliveira, G., Chernicharo, C.A., de Araújo, J.C., 2016. Metagenomic analysis of a desulphurisation system used to treat biogas from vinasse methanisation. Bioresour. Technol. 205, 58-66.

[17] Donkin, S.S., Doane, P.H., Cecava, M.J., 2013. Expanding the role of crop residues and biofuel co-products as ruminant feedstuffs. Anim. Front. 3(2), 54-60.

[18] Ennouri, H., Miladi, B., Diaz, S.Z., Güelfo, L.A.F., Solera, R., Hamdi, M., Bouallagui, H., 2016. Effect of thermal pretreatment on the biogas production and microbial communities balance during anaerobic digestion of urban and industrial waste activated sludge. Bioresour. Technol. 214, 184-191.

[19] Esposito, G., Frunzo, L., Panico, A., Pirozzi, F., 2012. Enhanced biomethane production from co-digestion of different organic wastes. Environ. Technol. 33(24), 2733-2740.

[20] Forgács, G., Pourbafrani, M., Niklasson, C., Taherzadeh, M.J, Sárvári Horváth, I., 2012. Methane production from citrus wastes: Process development and cost estimation. J. Chem. Technol. Biotechnol. 87(2), 250-255.

[21] Garcia, S.G., 2005. Farm scale anaerobic digestion integrated in an organic farming system. JTI (Institutet för Jordbruks-och Miljöteknik). Report, 34.

[22] Griffin, M.E., McMahon, K.D., Mackie, R.I., Raskin, L., 1998. Methanogenic population dynamics during start-up of anaerobic digesters treating municipal solid waste and biosolids. Biotechnol. Bioeng. 57(3), 342-355.

[23] Heeg, K., Pohl, M., Sontag, M., Mumme, J., Klocke, M., Nettmann, E., 2014. Microbial communities involved in biogas production from wheat straw as the sole substrate within a two-phase solid-state anaerobic digestion. Syst. Appl. Microbiol. 37(8), 590-600.

[24] Hendriks, A.T.W.M., Zeeman, G., 2009. Pretreatments to enhance the digestibility of lignocellulosic biomass. Bioresour. Technol. 100(1), 1018.

[25] Himmel, M.E., Baker, J.O., Overend, R.P., 1994. Enzymatic Conversion of Biomass for Fuels Production. American Chemical Society, Washington DC.

[26] Holm-Nielsen, J.B., Al-Seadi, T., Lens, P., Hamelers, B., Hoitink, H., Bidlingmaier, W., 2004. Manure-based biogas systems-Danish experience, in: Lens, P., Hamelers, B., Hoitink, H., Bidlingmaier, W. (Eds.), Resource recovery and reuse in organic solid waste management. IWA Publishing, London, UK, pp. 377-394.

[27] Hoornweg, D., Bhada-Tata, P., 2012. What a waste: a global review of solid waste management. World Bank.

[28] Huttunen, S., Kivimaa, P., Virkamäki, V., 2014. The need for policy coherence to trigger a transition to biogas production. Environ. Innovat. Soc. Transit. 12, 14-30

[29] Jin, S., Chen, H., 2006. Superfine grinding of steam-exploded rice straw and its enzymatic hydrolysis. Biochem. Eng. J. 30(3), 225-230.
[30] Judd, S., 2010. The MBR book, principles and applications of membrane bioreactors for water and wastewater treatment. Elsevier, Oxford.

[31] Kabir, M.M., del Pilar Castillo, M., Taherzadeh, M.J., Sárvári Horváth, I., 2013. Enhanced methane production from forest residues by $\mathrm{N}$-methylmorpholine-N-oxide (NMMO) pretreatment. BioResources. 8(4), 5409-5423.

[32] Kabir, M.M., Rajendran, K., Taherzadeh, M.J., Sarvari Horvath, I., 2015. Experimental and economical evaluation of bioconversion of forest residues to biogas using organosolv pretreatment. Bioresour. Technol. 178, 201-208.

[33] Kacprzak, A., Krzystek, L., Ledakowicz, S., 2010. Co-digestion of agricultural and industrial wastes. Chem. Pap. 64(2), 127-131.

[34] Kovács, E., Wirth, R., Maróti, G., Bagi, Z., Rákhely, G., Kovács, K.L., 2013. Biogas production from protein-rich biomass: fed-batch anaerobic fermentation of casein and of pig blood and associated Changes in microbial community composition. PLoS One. 8(10), e77265.

[35] Lehtomäki, A., 2006. Biogas production from energy crops and crop residues. University of Jyväskylä.

[36] Lennartsson, P.R., Niklasson, C., Taherzadeh, M.J., 2011. A pilot study on lignocelluloses to ethanol and fish feed using NMMO pretreatment and cultivation with zygomycetes in an air-lift reactor. Bioresour. Technol. 102(6), 4425-4432.

[37] Lin, H., Liao, B-Q., Chen, J., Gao, W., Wang, L., et al., 2011. New insights into membrane fouling in a submerged anaerobic membrane bioreactor based on characterization of cake sludge and bulk sludge. Bioresour. Technol. 102(3), 2373-2379.

[38] Luo, G., Angelidaki, I., 2014. Analysis of bacterial communities and bacterial pathogens in a biogas plant by the combination of ethidium monoazide, PCR and Ion Torrent sequencing. Water Res. 60, 156163.

[39] Luo, G., Wang, W., Angelidaki, I., 2013. Anaerobic Digestion for Simultaneous Sewage Sludge Treatment and CO Biomethanation: Process Performance and Microbial Ecology. Environ. Sci. Technol. 47(18), 10685-10693.

[40] Ma, J., Zhao, Q-B., Laurens, L.L.M., Jarvis, E.E., Nagle, N.J., et al., 2015. Mechanism, kinetics and microbiology of inhibition caused by long-chain fatty acids in anaerobic digestion of algal biomass Biotechnol. Biofuels. 8(1), 1-12

[41] Mata-Alvarez, J., Mace, S., Llabres, P., 2000. Anaerobic digestion of organic solid wastes. An overview of research achievements and perspectives. Bioresour. Technol. 74(1), 3-16.

[42] Merlin Christy, P., Gopinath, L.R., Divya, D., 2014. A review on anaerobic decomposition and enhancement of biogas production through enzymes and microorganisms. Renew. Sust. Energy Rev. $34,167-173$.

[43] Misi, S.N., Forster, C.F., 2001. Batch co-digestion of multicomponent agro-wastes. Bioresour. Technol. 80(1), 19-28.

[44] Møller, H.B., Sommer, S.G., Ahring, B.K., 2004. Methane productivity of manure, straw and solid fractions of manure. Biomass Bioenergy. 26(5), 485-495.

[45] Monavari, S., Galbe, M., Zacchi, G., 2009. Impact of impregnation time and chip size on sugar yield in pretreatment of softwood for ethanol production. Bioresour. Technol. 100(24), 6312-6316.

[46] Nielsen, L.H., Hjort-Gregersen, K., Thygesen, P., Christensen, J. 2002. Samfundsøkonomiske analyser af biogasf llesanlg. Fødevare $\varnothing$ konomisk Institut, Rapport, 136.

[47] Ozgun, H., Dereli, R.K., Ersahin, M.E., Kinaci, C., Spanjers, H., van Lier J.B., 2013. A review of anaerobic membrane bioreactors for municipal wastewater treatment: Integration options, limitations and expectations. Sep. Purif. Technol. 118, 89-104.

[48] Pagés Díaz, J., Pereda Reyes, I., Lundin, M., Sárvári Horváth, I., 2011. Co-digestion of different waste mixtures from agro-industrial activities: Kinetic evaluation and synergetic effects. Bioresour. Technol. 102(23), 10834-10840.

[49] Pagés-Díaz, J., Pereda-Reyes, I., Taherzadeh, M.J., Sárvári-Horváth, I., Lundin, M., 2014. Anaerobic co-digestion of solid slaughterhouse wastes with agro-residues: Synergistic and antagonistic interactions determined in batch digestion assays. Chem. Eng. J. 245, 89-98. 
[50] Pagés-Díaz, J., Westman, J., Taherzadeh, M.J., Pereda-Reyes, I., Sárvári Horváth, I., 2015. Semi-continuous co-digestion of solid cattle slaughterhouse wastes with other waste streams: Interactions within the mixtures and methanogenic community structure. Chem. Eng. J. 273, 28-36.

[51] Rakotojaona, L., 2013. Domestic biogas development in developing countries ENEA Consulting.

[52] Persson, M., Jönsson, O., Wellinger, A., 2006. Biogas upgrading to vehicle fuel standards and grid injection. IEA Bioenergy, Task, 37.

[53] Pore, S.D., Shetty, D., Arora, P., Maheshwari, S., Dhakephalkar, P.K., 2016. Metagenome changes in the biogas producing community during anaerobic digestion of rice straw. Bioresour. Technol. doi:10.1016/j.biortech.2016.03.045

[54] Raven, R., Gregersen, K.H., 2007. Biogas plants in Denmark: successes and setbacks. Renew. Sust. Energy Rev. 11(1), 116-132.

[55] Riviere, D., Desvignes, V., Pelletier, E., Chaussonnerie, S., Guermazi, S., et al., 2009. Towards the definition of a core of microorganisms involved in anaerobic digestion of sludge. ISME J. 3(6), 700-714.

[56] Salminen, E., Rintala, J., 2002. Anaerobic digestion of organic solid poultry slaughterhouse waste-a review. Bioresour. Technol. 83(1), 1326.

[57] Seppälä, M., Paavola, T., Rintala, J., 2007. Methane yields of different grass species on the second and third harvest in boreal conditions. Proc. $11^{\text {th }}$ IWA World Congress on Anaerobic Digestion, Brisbane, Australia. pp. 23-27.

[58] Schmidt, J.E., Ahring, B.K., 1996. Granular sludge formation in upflow anaerobic sludge blanket (UASB) reactors. Biotechnol. Bioeng. 49(3), 229-246.

[59] Bojesen, M., Boerboom, L., Skov-Petersen, H., 2014. Towards a sustainable capacity expansion of the Danish biogas sector. Land Use Policy 42, 264-277.

[60] Suksong, W., Kongjan, P., Prasertsan, P., Imai, T., O-Thong, S., 2016. Optimization and microbial community analysis for production of biogas from solid waste residues of palm oil mill industry by solid-state anaerobic digestion. Bioresour. Technol. 214, 166-174.

[61] Taherzadeh, M., Karimi, K., 2008. Pretreatment of lignocellulosic wastes to improve ethanol and biogas production: a review. Int. J. Mol. Sci. 9(9), 1621-1651

[62] Teghammar, A., Karimi, K., Sárvári Horváth, I., Taherzadeh, M.J., 2012. Enhanced biogas production from rice straw, triticale straw and softwood spruce by NMMO pretreatment. Biomass Bioenergy. 36, 116120 .

[63] VanGuilder, H.D., Vrana, K.E., Freeman, W.M., 2008. Twenty-five years of quantitative PCR for gene expression analysis. Biotechniques. 44(5), 619- 626.

[64] Visvanathan, C., Abeynayaka, A., 2012. Developments and future potentials of anaerobic membrane bioreactors (AnMBRs). Membr. Water. Treat. 3, 1-23.

[65] Vavilin, V.A., Rytov, S.V., Lokshina, L.Y., 1996. A description of hydrolysis kinetics in anaerobic degradation of particulate organic matter. Bioresour. Technol. 56(2), 229-237.

[66] Wang, H., Vuorela, M., Keränen, A-L., Lehtinen, T.M., Lensu, A., Lehtomäki, A., Rintala, J., 2010. Development of microbial populations in the anaerobic hydrolysis of grass silage for methane production. FEMS Microbiol. Ecol. 72(3), 496-506.

[67] Wang, L.H., Wang, Q., Cai, W., Sun, X., 2012. Influence of mixing proportion on the solid-state anaerobic co-digestion of distiller's grains and food waste. Biosyst. Eng. 112(2), 130-137.

[68] Wang, W., Xie, L., Luo, G., Zhou, Q., Angelidaki, I., 2013. Performance and microbial community analysis of the anaerobic reactor with coke oven gas biomethanation and in situ biogas upgrading. Bioresour. Technol. 146, 234-239.

[69] Ward, A.J., Hobbs, P.J., Holliman, P.J., Jones, D.L., 2008. Optimisation of the anaerobic digestion of agricultural resources. Bioresour. Technol. 99(17), 7928-7940.

[70] Wijekoon, K.C., Visvanathan, C., Abeynayaka, A., 2011. Effect of organic loading rate on VFA production, organic matter removal and microbial activity of a two-stage thermophilic anaerobic membrane bioreactor. Bioresour. Technol. 102(9), 5353-5360.
[71] Wikandari, R., Youngsukkasem, S., Millati, R., Taherzadeh, M.J., 2014. Performance of semi-continuous membrane bioreactor in biogas production from toxic feedstock containing D-Limonene Bioresour. Technol. 170, 350-355.

[72] Wilkinson, K.G., 2011. A comparison of the drivers influencing adoption of on-farm anaerobic digestion in Germany and Australia. Biomass Bioenergy. 35(5), 1613-1622.

[73] Xie, K., Lin, H.J., Mahendran, B., Bagley, D.M., Leung, K.T., Liss, S.N., Liao, B.Q., 2010. Performance and fouling characteristics of a submerged anaerobic membrane bioreactor for kraft evaporator condensate treatment. Environ. Technol. 31(5), 511-521.

[74] Yang, B., Wyman, C.E., 2008. Pretreatment: the key to unlocking low-cost cellulosic ethanol. Biofuels, Bioprod. Biorefin. 2(1), 2640

[75] Ylitervo, P., Akinbomia, J., Taherzadeha, M.J., 2013. Membrane bioreactors' potential for ethanol and biogas production: a review. Environ. Technol. 34(13-14), 1711-1723.

[76] Yong, Z., Dong, Y., Zhang, X., Tan, T., 2015. Anaerobic codigestion of food waste and straw for biogas production. Renew. Energ. 78, 527-530.

[77] Youngsukkasem, S., Akinbomi, J., Rakshit, S.K., Taherzadeh, M.J., 2013. Biogas production by encased bacteria in synthetic membranes: protective effects in toxic media and high loading rates. Environ. Technol. 34(13-16), 2077-2084.

[78] Youngsukkasem, S., Chandolias, K., Taherzadeh, M.J., 2015. Rapid bio-methanation of syngas in a reverse membrane bioreactor: membrane encased microorganisms. Bioresour. Technol. 178, 334 340.

[79] Youngsukkasem, S., Rakshit, S.K., Taherzadeh, M.J., 2012. Biogas production by encapsulated methane-producing bacteria BioResources. 7(1), 56-65.

[80] Zahedi, S., Sales, D., Romero, L.I., Solera, R., 2013. Optimisation of single-phase dry-thermophilic anaerobic digestion under high organic loading rates of industrial municipal solid waste: population dynamics. Bioresour. Technol. 146, 109-117.

[81] Zakrzewski, M., Goesmann, A., Jaenicke, S., Jünemann, S., Eikmeyer, F., Szczepanowski, R., Al-Soud, W.A., Sørensen, S., Pühler, A., Schlüter, A., 2012. Profiling of the metabolically active community from a production-scale biogas plant by means of highthroughput metatranscriptome sequencing. J. Biotechnol. 158(4), $248-258$

[82] Zeng, M., Mosier, N.S., Huang, C.P., Sherman, D.M., Ladisch, M.R., 2007. Microscopic examination of changes of plant cell structure in corn stover due to hot water pretreatment and enzymatic hydrolysis. Biotechnol. Bioeng. 97(2), 265-278.

[83] Zhang, Y.H.P., 2008. Reviving the carbohydrate economy via multiproduct lignocellulose biorefineries. J. Ind. Microbiol. Biotechnol. 35(5), 367-375. 